\title{
Propaganda e religião em Portugal: festivais de música ligeira (1958-1964)
}

\section{Propaganda and religion in Portugal: popular music festivals (1958-1964)}

\author{
João Ricardo Pinto* \\ Nuno Estêvão Ferreira**
}

\begin{abstract}
Resumo: A relação entre o Estado e a Igreja Católica ao longo do período do Estado Novo atravessou diferentes momentos, especialmente no $3^{\circ}$ quartel do século XX, quando se verificaram diferentes tensôes no plano das relaçôes institucionais. Para além destas, o texto analisa outros níveis de observação que importa conhecer, nomeadamente, a importância das práticas culturais expressivas associadas à música. Nesse sentido, e partindo do cruzamento do poder do Estado com a presença de temáticas religiosas na música ligeira desenvolvida propositadamente para os festivais de música, este texto procura discutir o papel desta categoria musical como elemento de propaganda religiosa na sua interligação com o poder político.
\end{abstract}

Palavras-chave: Estado Novo. Religião. Festivais de Música. Música ligeira. Propaganda.

Abstract: The relation between the State and the Catholic Church throughout the Estado Novo period went through different moments. This was especially so in the 3rd quarter of the 20th century period, during which several tensions occurred in institutional relations. In addition to these elements, this text analyzes other observation levels that may contribute to knowledge-gathering, specifically expressive cultural practices associated with music. Thus, starting from the intersection of state power on the one hand, and the presence of religious themes in so-called popular music, specifically developed for music festivals, on the other, this text aims to discuss the role of this musical category as a tool of religious propaganda in its interconnection with political power.

Keywords: New State. Religion. Song Contest. Popular music. Propaganda.

\section{Introduçáo}

Desde a aprovação da Constituição da República Portuguesa de 1933 até à Revolução de 25 de Abril de 1974, Portugal viveu sob um regime político autoritário, conservador, nacionalista e corporativista. Entre os organismos com que Salazar dotou o Estado Novo, encontrava-se o Secretariado de Propaganda Nacional (SPN), o qual, em 1944, assumiu a designação de Secretariado Nacional de Informação, Cultura Popular e Turismo (SNI). O seu papel foi preponderante do ponto de vista artístico-musical, na organização de concursos e festivais em torno da música e nos apoios cedidos a iniciativas de outras

\footnotetext{
* Professor de Música do IPL (Portugal). Doutor em Ciências Musicais (UNL). Investigador Colaborador no INET-md. ORCID: 0000-0001-5788-8934 - contato: jrpinto@fcsh.unl.pt

* Doutor em Ciências Sociais (ULisboa, Portugal). Membro do UCP-CEHR. ORCID: 0000-00020468-2745 - contato: n.estevao.ferreira@gmail.com
} 
instituições, públicas e privadas. Assegurar a difusão de um ideário nacionalista, tradicional e conservador e garantir que a criatividade cultural se processava de acordo com os mesmos princípios eram objetivos centrais (Paulo, 1994, p. 73-137).

Situada no plano ideológico do exercício do poder do Estado, esta estratégia visava a mobilizaçáo da população em torno da nova ordem política, económica, cultural e social. A adesão dos grupos sociais ao novo regime e o seu enquadramento e disciplina eram objetivos primordiais (Melo, 2001). Os responsáveis pelo Estado Novo pretendiam, ainda, impedir, por antecipação e com recurso à ocupaçấo do espaço cultural, a introdução de outros ideários, por intermédio de um duplo poder: de influência e de injunçáo (Ó, 1999). No campo cultural, os objetivos dos recursos mobilizados pela ditadura eram complementares de instrumentos mais repressivos, como a polícia política, os tribunais plenários ou a censura prévia, a par da proibição da formação de outros partidos políticos, que não o partido único (União Nacional) e da constituição de organizaçóes livres de trabalhadores e patrôes, alheias aos organismos corporativos (sindicatos nacionais, grémios ou casas do povo).

Enquanto ideólogo do regime e responsável pela política cultural do Estado Novo, tanto como diretor do SNI (1933-1949) como da Emissora Nacional de Radiodifusão (1941-1949), vulgarmente conhecida por Emissora Nacional (EN), António Ferro colocou em prática a sua formulação doutrinária a que chamou Política do Espírito (Guedes, 1997; Santos, 2008). Um plano de açáo de política cultural "arbitrado pelo Estado e ao serviço da Nação que procurou o equilíbrio entre a tradição e a modernidade" (Moreira, 2012, p. 84). Os seus momentos de maior afirmaçáo foram o Duplo Centenário e a Exposição do Mundo Português, em 1940, e na sua base estava uma política de fomento cultural, subordinada aos fins políticos do regime, como forma de legitimação dos ideais do Estado Novo.

Após 1949, os sucessores de Ferro no SNI prosseguem os objetivos da Política do Espírito. Entre 1958 e 1968, César Moreira Baptista revelou uma grande preocupação com a imagem do regime no estrangeiro; no caso do cinema com a participação no Festival de Cannes, em 1959, ou da música com a participação no Grande Prémio Eurovisão da Canção (GPEC), em 1964. Para além de pretender consensos a nível interno, a continuidade da Política do Espírito visou também estruturar a imagem de Portugal no estrangeiro (Alves, 2003, p. 192).

Enquanto sistema político ditatorial e com elevado grau de centralização na figura de Salazar, do ponto de vista do processo de decisão política (Carvalho; Raimundo; Ferreira, 2012), o regime em vigor em Portugal promoveu a difusão dos méritos da sua figura máxima como estratégia política ou a "narrativa histórica personalizada na vontade de um homem" (Domingos; Pereira, 2010, p. 7). O "mago das Finanças" ou o "asceta das Finanças" (Matos, 2003) foram das primeiras imagens difundidas sobre o professor de Coimbra, desprovido de ambiçóes políticas e que não fossem o serviço da nação.

A carreira política de Salazar remonta, contudo, à I República e ao Centro Católico Português, partido formado durante a I Guerra (Meneses, 2010, p. 12-31), no quadro de um intenso conflito entre o regime republicano e a Igreja Católica (Moura, 2010). Figura marcante do partido católico, Salazar foi por duas vezes candidato a deputado, 
chegando inclusivamente a ser eleito, naquela que foi a mais curta legislatura da I República. Já durante a Ditadura Militar, recorreu às páginas do jornal oficioso da Igreja Católica, Novidades, para criticar de forma sistemática a política financeira daquele a quem viria a suceder, em 1928, como ministro das Finanças. Nessa pasta, Salazar torna-se a figura decisiva de governos sucessivos (Lucena, 2000, p. 322-333). A tal ponto que, depois de ser o elemento central em crises políticas que conduzem à queda de frágeis executivos, num dos casos, devido à questão religiosa (Carvalho; Araújo, 2006), Salazar será a peça-chave em torno da qual são formados os novos governos e definidas as linhas-mestras do novo regime (Cruz, 1985).

Antes da edificação, em 1933, do novo regime político, por cuja conceção é igualmente responsável, e de assegurar, no ano imediatamente anterior, a Presidência do Conselho de Ministros, a carreira política de Salazar não é, portanto, escassa, ao contrário da imagem difundida pela propaganda do Estado Novo. A sua formação católica remontava ao Seminário de Viseu e o seu ativismo no movimento católico desenvolvera-se no embate com o regime republicano enquanto estudante na Faculdade de Direito na Universidade de Coimbra. Foi aí que esteve envolvido na reativação do Centro Académico de Democracia Cristá (CADC) e no jornal Imparcial, dirigido por Manuel Gonçalves Cerejeira, seu amigo pessoal, futuro Cardeal Patriarca de Lisboa e figura central na Igreja Católica em Portugal até final dos anos 1960 (Matos, 2018).

A nomeação de Salazar como governante correspondia ao recrutamento de um professor de Finanças, com expressão pública e reiterada de críticas incisivas às políticas que vinham a ser adotadas pelos governantes de 1927-1928. Mas a área política em que a sua atividade pública tinha sido exercida permitia sugerir uma nova posição da Igreja Católica junto dos órgáos do poder político, distinta daquela que marcara os primeiros tempos da I República, quando se sucederam profundas polémicas, desde a expulsão das ordens religiosas à Lei de Separação do Estado e das Igrejas (Pinto, 2011; Matos, 2011).

Contudo, Salazar, através do jornal Novidades (27 abr., 1928), esclarece, logo no próprio dia da sua posse como ministro das Finanças, o tipo de relação com o universo católico. Para o novo governante, o campo político onde se formara e se destacara não permitia supor que a Igreja Católica passasse a exercer, por seu intermédio, uma influência direta sobre o Estado, nem que àquela fosse atribuída uma posiçáo privilegiada para garantir antigas reivindicaçóes. E se a amizade pessoal com Cerejeira se manteve, como atesta a correspondência que este lhe dirigiu (Carvalho, 2010), a sintonia de interesses entre ambos não foi a pedra de toque, com sucessivas divergências a confirmarem idênticas posiçôes, de chefia, mas a partir de campos distintos, o Estado e a Igreja. A Concordata (1940) viria a consagrar o regime de separação, ainda que os seus termos e a própria existência de um acordo diplomático conferissem à Igreja Católica uma posição preferencial entre as restantes confissóes religiosas (Carvalho, 2013).

O regime de Salazar caracterizar-se-ia por uma grande ambiguidade nas relaçóes entre o Estado e a Igreja Católica (Simpson, 2014). O catolicismo forneceu elementos centrais para o cimento ideológico do novo regime. A conceção da ordem social com base na tradição e na estabilidade, o modelo de família, o lugar da mulher na sociedade ou a matriz das políticas de educação ou de assistência são alguns exemplos. A visão 
sobre a sociedade que a propaganda do Estado Novo difundiu foi devedora do ideário católico e as imagens da nação e do povo assentavam numa matriz religiosa e tradicional. Para António Ferro $(1935$, p. 6), a "obra da propaganda nacional" requeria "a frente comum dos princípios morais e espirituais que nos foram legados pelo cristianismo". Para o estratega do SPN, a Nação e a Igreja viam-se, agora, "com simpatia, quási amorosamente" porque "Deus e Portugal andaram sempre juntos (Ferro, 1935, p. 8).

A campanha presidencial de Humberto Delgado, em 1958, foi ocasião de uma manifesta tensão entre o Estado e a Igreja Católica. Alguns católicos subscreveram manifestos a contestar a proximidade entre a Igreja e o regime. Salazar reagiu de forma violenta e, em face do que considerou ser a rutura no que considerava ser a "frente nacional", ameaçou colocar em causa a Concordata e o futuro das relaçóes entre o Estado e a Igreja Católica (Salazar, 1959, p. 513-527).

Um primeiro documento colocou em causa a imparcialidade do jornal oficioso da Igreja Católica, Novidades, no acompanhamento da campanha eleitoral (Alves, 1970, p. 11-16). Outros textos centraram-se na relação entre a Igreja Católica e o Estado (Alves, 1970, p. 65-88) e nos meios de repressão do regime (Alves, 1970, p. 89-113). Neste último, era invocado o facto de o governo e o regime serem classificados como de "inspiração cristã e baluartes da Igreja Católica em Portugal" (Alves, 1970, p. 91).

A divulgação da carta que D. António Ferreira Gomes, bispo do Porto, dirigiu a Salazar a contestar o regime ditatorial foi peça decisiva para a tensão nas relaçóes institucionais entre o Estado Novo e a Igreja Católica (Alves, 1970, p. 31-64). Seria incontornável o impacto público das questóes colocadas por um bispo sobre a governação de Salazar, agravado pelo exílio de dez anos a que foi sujeito pelo regime ditatorial.

Em 1958, a questão colocada por Salazar em reação aos manifestos ou à carta do bispo do Porto não era somente o apoio ao candidato do regime, o tipo de mobilizaçáo dos católicos ou a sua participaçáo política. Para o chefe do Estado Novo, o problema era, sobretudo, ideológico. A visão de sociedade que o catolicismo fornecia e o enquadramento dos grupos sociais que era proporcionado pelo ideário católico favorecia a paz social e a harmonia entre as classes. O conservadorismo, o tradicionalismo e o nacionalismo eram imagens de marca que importava sustentar. A imagem de um país maioritariamente rural com posições sociais tipicamente estáveis, com baixo grau de industrialização e sem processos de massificação, oferecia garantias contra a permeabilidade ao ideário da luta de classes ou da democracia.

Aos "anos de chumbo" (Rosas, 1994, p. 503-523) do salazarismo sucederia, entre 1958 e 1962, a segunda grande crise do regime, marcada, sobretudo, pelo "terramoto delgadista" (Rosas, 1994, p. 523-539) e, depois, pelo início da guerra em Angola, para além de outros momentos de tensão. A segunda metade da década de 1960 será ainda mais intensa. Contudo, é ainda na primeira metade da década que as repercussóes das "mudanças invisíveis" (Rosas, 1994, p. 419-501) do pós-guerra, e as alteraçôes provocadas no ideário católico com epicentro no Concílio Vaticano II (1961-1965), que representam mais uma perda para a estabilidade do regime, vão sendo preparadas. Aquele que fora um importante alicerce começa, enquanto cimento ou elo de ligação de um regime (Ferreira, 1990, p. 402), a esboroar-se de forma inexorável.

Como categoria musical intrinsecamente ligada à "emergência dos meios de 
comunicação de massa, da indústria da música e de novas formas de entretenimento urbano" (Moreira; Cidra; Castelo-Branco, 2010, p. 872), a música ligeira servia os interesses comuns do Estado e da Igreja Católica. Por estar associada a processos de produção e comercialização massificada pelas indústrias culturais, a música ligeira, que teve na canção o seu género principal e daí ser recorrentemente designada de canção ligeira, aproxima-se da designação popular music da cultura anglo-saxónica (CasteloBranco; Cidra, 2010, p. 875). Contudo, a presença de temáticas religiosas não é exclusiva da música ligeira, nem sequer do período. Já anteriormente se verificava em categorias como, por exemplo, no fado (Tuna 2020).

Partindo do conceito de "teologia pop" (Alizart, 2015, nossa tradução), importa correlacionar de modo sistemático os dados empíricos que nos permitam compreender de que forma a teologia ligeira, uma interligação da presença de temáticas religiosas nos festivais de música ligeira, foi um veículo ideológico de rutura ou, se pelo contrário, incorporava elementos comuns, do Estado e da Igreja Católica, que garantisse o equilíbrio social desejado.

\section{Festivais de música}

É na transição entre os "anos de chumbo" (Rosas, 1994, p. 503-523) e a segunda crise do regime no rescaldo do "terramoto delgadista" (Rosas, 1994, p. 523-539) que têm lugar três importantes eventos de música ligeira: o Festival da Cançáo Portuguesa, o Concurso de Cançóes Ligeiras e o Io Grande Prémio TV da Canção Portuguesa.

Contudo, importa referir que a partir de 1942, ainda durante a guerra, a EN, sob orientação de António Ferro, organiza o Concurso Anual de Artistas de Rádio (Silva, 2010, p. 1084), evento que se enquadrou no objetivo de transfigurar a EN num braço inequívoco da ação e propaganda do SPN/SNI (Moreira, 2012). Procurava-se a renovação do repertório musical realizada através da recolha, catalogação, notação, passando pela harmonização e gravação de música de vários domínios musicais que tinham por base melodias rurais ou composiçóes originais com base no folclore: o "aportuguesamento" da "música ligeira" (Moreira, 2012, grifos do autor). Embora tenha sido organizado anualmente, ainda hoje se sabe muito pouco relativamente a este concurso, nomeadamente no que diz respeito aos repertórios, intérpretes, compositores ou mesmo relativamente ao seu término.

No campo cultural o termo concurso está genericamente mais associado a um momento de competição. Contudo, as expressóes festival e concurso eram usadas de uma forma indiferenciada no domínio musical. Referem-se a eventos musicais organizados num espaço e tempo determinados. Espetáculos musicais ao vivo, geralmente transmitidos pela televisáo e/ou rádio que, no presente contexto, eram dedicados a uma categoria musical específica, a música ligeira; no entanto existiam muitos outros dedicados ao folclore, à música erudita, ao jazz etc.

Ao contrário do folclore, prática expressiva que pretendia evocar a cultura popular, enquanto "património <<autêntico>> da população rural" (Castelo-Branco; Cidra, 2010, p. 876), a música ligeira, assumida como elemento central neste tipo de eventos, 
estava muito associada aos meios de comunicação, à indústria da música e ao entretenimento urbano enquanto experiência de consumo; uma conceção mais moderna dos comportamentos expressivos que surgiam da sua relação com o mainstream musical.

Embora nalguns casos não tivessem tido uma componente competitiva, como no caso do I Festival da Cançáo Portuguesa ao qual nos iremos dedicar de seguida, a presença de um júri selecionado pelos diversos organizadores, parece ter tido um papel preponderante para o sucesso de algumas cançóes, bem como, de alguns intérpretes vocais; vulgarmente referidos como vedetas quando passavam a ter uma presença regular nos meios de comunicação.

As avaliaçóes realizadas pelos júris atribuíam escalas de valor que, nalguns casos, viriam a ser determinantes tanto para a possibilidade de gravar em fonogramas, como para a publicação das partituras em versões para piano e voz, das cançôes com melhores classificações. No caso do I Concurso de Cancóes Ligeiras (1960) tanto as "gravaçôes em disco" como a "imediata publicação por uma casa editora de Lisboa”, estavam previstas no regulamento como prémios; o que evidencia a importância deste tipo de eventos musicais para indústria da música.

\section{O Festival da Cançáo Portuguesa}

Referida pela imprensa escrita desde agosto de 1957, a organização do I Festival da Canção Portuguesa é confirmada a 12 de janeiro de 1958 na notícia "O I Festival da Canção portuguesa será a 21 de janeiro":

[...] damos aos nossos leitores a grata notícia de que vai ser um facto o I Festival da Canção Portuguesa, que o Centro de Preparação de Artistas da Rádio, da Emissora Nacional, sob a direcçáo do professor Mota Pereira, vai imediatamente levar a cabo (RTV, 12 jan., 1958).

Sem componente competitiva, com orquestraçóes do maestro Fernando Carvalho e acompanhamento musical da Orquestra Ligeira da EN (Flama, 31 jan., 1958), o festival teve lugar na noite de 21 de janeiro no Cinema Império (Lisboa).

Apresentadas no artigo de opinião "A Bem da Nação" pela ordem de preferência da equipa editorial da própria revista Flama (31 jan., 1958), somos informados de que foram apresentadas treze cançóes e que a cançáo merecedora do primeiro lugar seria "Lisboa, Feliz". Com música de Manuel Paião e letra de Eduardo Damas, esta parece ter sido interpretada pela cançonetista Milú; canção que viria a ser gravada num disco intitulado Lisbonna (Alvorada MEP 60105) por Maria de Lurdes Resende; com acompanhamento do Conjunto Shegundo Galarza, ainda em 1958.

Contrariamente, na revista Rádio e Televisão (RTV) de 26 de janeiro de 1958, após uma descrição de todas as cançôes apresentadas, é afirmado que a vencedora deveria ter sido a canção "Vocês Sabem Lá...”, interpretada por Maria de Fátima Bravo. Posteriormente esta canção viria a ser editada num disco com o mesmo nome, pela DECCA Records (P-DFE 6489). A 12 de janeiro de 1958, na mesma revista, é afirmado que este festival tinha como principal finalidade "apresentar, num só programa, os mais representativos compositores da música ligeira portuguesa”, estando em estudo 
a sua repetição no Porto e em Coimbra, o que se veio a verificar nas edições seguintes, como veremos mais à frente.

Das treze cançôes presentes em 1958, e muito embora algumas incluam referências religiosas como por exemplo "serias a luz e a cruz da minha vida" na letra da cançáo intitulada "Maria do Céu", apenas uma é inteiramente consagrada à temática religiosa: "Senhora da Nazaré". Com letra e música de João Nobre, e interpretação de Domingos Marques, faz referência à fragilidade humana na sua relação com a dimensão divina. Embora existam várias versões ao longo dos anos, foi gravada pela primeira vez por Tristão da Silva no EP ${ }^{1}$ coletivo Nazaré (DECCA-PDFE 6525), em 1958. Dois anos mais tarde, a editora Sasseti publicou uma versão impressa para piano e voz.

Cerca de dois anos e meio mais tarde, a 1 de junho de 1960, a EN e o SNI organizaram o IIo Festival da Canção Portuguesa (RTV, 11 junho, 1960). O objetivo de levar o festival organizado à cidade do Porto, desejado desde a sua primeira ediçáo, conforme suprarreferido, é concretizado na sua segunda edição.

Dividido em duas partes, sendo a primeira dedicada a novos autores e a segunda aos autores já consagrados, o seu objetivo já não era só mostrar os mais representativos compositores da música ligeira portuguesa, mas abrir espaço para que surgissem novos letristas e novos compositores, o que não se verificou na edição anterior, em 1958. A avaliação esteve a cargo de um júri formado por Jaime Ferreira, pela compositora Berta Alves de Sousa e pelos poetas Heitor de Campos Monteiro e Silva Tavares.

Embora a segunda edição do Festival da Canção Portuguesa tenha originado um grande número de discos, nomeadamente das ediçóes Alvorada e A Voz do Dono, Rodrigues Piteira, na rubrica "Nos Bastidores", afirma que, "para nós, não existiu o II Festival da Canção Portuguesa" (Flama, 24 junho, 1960); uma crítica clara à organização do festival, que não teve a preocupação de informar devidamente a imprensa sobre o que iria ser este evento e, posteriormente, sobre quais os resultados do mesmo. A falta de divulgação do festival já tinha sido criticada por uma das principais intérpretes da época, Maria de Lurdes Resende, na notícia "O II Festival da Canção Portuguesa realizado no Coliseu do Porto foi uma feliz iniciativa da E.N.” (RTV, 11 junho, 1960).

No Coliseu do Porto ouviram-se dezasseis cançôes das quais duas de índole religiosa: "Crucifixo" (letra de Eduardo S. Oliveira e música de Jaime Baena) e "À Porta da Casa do Nosso Senhor" (letra de Silva Tavares e música de António Melo), interpretadas por Maria Candal e Maria Teresa (Teresinha), respetivamente. Estas intérpretes viriam a gravar em dois EP's coletivos, ambos intitulados II Festival da Canção Portuguesa, da editora Alvorada: "Crucifixo" (MEP 60292), e "À Porta da Casa do Nosso Senhor" (MEP 60283). À imagem do que se verificou na primeira ediçáo do festival, também estas duas cançóes foram editadas em música impressa, para piano e voz, pela editora Sasseti, em 1960.

O III Festival da Canção Portuguesa teve lugar no Casino Peninsular da Figueira da Foz (distrito de Coimbra), nos dias 20 e 21 de agosto de 1961. O facto de em três edições ter sido organizado em três cidades diferentes mostra a intenção de cumprir o

1 Extended Play (EP) é o nome dado a um fonograma que contém entre quatro e seis faixas. Ou seja, maior que um Single (duas faixas) e menor que um Long Play (LP) que geralmente tem entre dez e doze faixas. 
objetivo inicial, de dotar este evento de um "carácter de acontecimento artístico nacional", que é cumprido em parte, pois, em três edições, esteve presente nos principais distritos portugueses: Lisboa, Porto e Coimbra.

Embora mantenha o objetivo de "estimular a produçáo e desenvolver a expansão e divulgação da música ligeira portuguesa" (Regulamento do II Festival da Canção Portuguesa 1961: art. $^{\circ}{ }^{\circ}$ ), a terceira ediçáo apresenta duas novidades: um prémio atribuído ao intérprete vencedor, o que não se tinha verificado nas duas ediçóes anteriores; e o desejo de projetar internacionalmente o festival. Segundo descrito na notícia da RTV de 1 de julho de 1961, esta intenção é revelada pela sua integração num intercâmbio com o Festival de la Canción de Benidorm.

Concorreram 114 canções, tendo o júri de seleção escolhido 10 para estarem presentes numa fase final que foi transmitida em direto pela Radiotelevisão Portuguesa (RTP) e pela EN, a partir das $22 \mathrm{~h}$ em dois dias consecutivos, 20 e 21 de agosto de 1961. Tratou-se de duas emissóes simultâneas, rádio e televisáo, ao longo de uma hora e quinze minutos cada. Importa reforçar que se tratou do primeiro festival de música ligeira transmitido em direto pela televisão portuguesa.

A capa da RTV de 26 de agosto de 1961, a primeira imediatamente a seguir à realização da terceira edição do Festival da Canção Portuguesa, é preenchida por Maria Clara, vencedora do Prémio de Interpretação. Na notícia intitulada "Os Grandes Êxitos do III Festival da Canção Portuguesa", é confirmada a presença da Orquestra Típica da EN dirigida por Tavares Belo e Fernando de Carvalho, publicada a letra de todas as cançóes do festival, e dada a conhecer a classificação final, bem como a identidade dos intérpretes. Das dez canções que fizeram parte deste evento, uma é dedicada à temática religiosa: "Oração para Dois" (letra de Vitorino de Sousa e música de Resende Dias).

O júri, constituído por Jaime Ferreira (presidente da direção da EN), Pedro do Prado (chefe da repartição musical da EN); Silva Pereira (maestro); Morais Cabral e Redondo Júnior (jornalistas), atribui a esta o quarto lugar, numa interpretação de uma das mais famosas cançonetistas da época, Maria de Fátima Bravo. Curiosamente, esta canção, que sublinha o amor e o perdáo, viria a ser editada em dois fonogramas: no EP coletivo $3^{\circ}$ Festival da Canção Portuguesa (DECCA - PEP 1028) com interpretação de Maria de Fátima Bravo, e no single coletivo Figueira da Foz - III Festival da Canção (Alvorada - AN-97.034), pela voz de Simone de Oliveira; ambos em 1961.

A 2 de setembro de 1961 é publicada, na RTV, uma notícia inteiramente dedicada à vertente internacional que se procurou imprimir à terceira edição do Festival da Canção Portuguesa. Este desejo é evidenciado pela presença dos embaixadores de Espanha e Brasil, bem como pela presença dos governadores civis de Alicante e Badajoz, na Figueira da Foz. Miguel Moscardó (governador de Alicante) e Aníbal Arias de Ruiz (diretor da Rede Espanhola de Emissores do Movimento) dão duas entrevistas publicadas na mesma edição da revista, tendo o último, no que diz respeito ao intercâmbio realizado entre Portugal e Espanha, afirmado que:

Está sendo cada vez mais necessário. Vivemos uma época agitada, difícil e um tanto complicada. Os países que são na verdade, autênticos amigos devem manter-se unidos e confiantes. A canção pode e é um forte elo de amizade que fortalece a união (RTV, 2 set., 1961). 
Para o diretor da Rede Espanhola de Emissores do Movimento, Aníbal Arias de Ruiz, a canção era um elemento de agregação. Contudo, o facto de ter sido noticiado que a "embaixada portuguesa será constituída por Simone de Oliveira, Madalena Iglésias, Alice Amaro e António Calvário" (RTV, 8 julho, 1961) e de nenhuns destes intérpretes ter apresentado no festival português qualquer cançáo de temática religiosa leva a crer que a canção "Oração para Dois" não fez parte do intercâmbio com o festival espanhol. Deste facto, podemos concluir que a escolha das cançóes para estarem presentes em Espanha não teve em conta a classificação do festival em Portugal. Caso contrário, e tendo a embaixada portuguesa integrado quatro intérpretes, a canção "Oração para Dois" deveria ter sido contemplada.

\section{Concurso de Cançóes Ligeiras}

O I Concurso de Cançōes Ligeiras foi o primeiro momento em que a RTP procurou criar fluxos musicais. Até aí o seu papel tinha sido de amplificação de fenómenos de outros campos culturais, como a rádio, o cinema, a indústria discográfica ou de concursos organizados por entidades fora do campo mediático (Pinto, 2019).

A análise do regulamento, publicado na RTV a 21 de maio de 1960, e dos resultados do concurso revelam que existia a intenção de selecionar uma canção que representasse Portugal no Concurso Internacional da Canção Ligeira da Eurovisão - hoje designado Festival Eurovisão da Canção - o que não se veio a verificar.

Os resultados do I Concurso de Cançôes Ligeiras, segundo noticiado pela RTV a 30 de julho de 1960, foram dados a conhecer num programa de variedades no dia 21 de julho de 1960. Na mesma notícia somos ainda informados de que o júri atribuiu os prémios das "quatro melhores cançôes" a "Ilusão de Amor" (letra e música de Jorge Costa Pinto), "Amanhã se Deus quiser..." (letra de Jerónimo de Bragança e música de Nóbrega e Sousa), "Recordando à Lareira" (letra e música de José António Robertes de Araújo Pereira) e "Talvez..." (letra e música de Carlos Canelhas).

Assim, podemos concluir que, muito embora Portugal se quisesse fazer representar no certame internacional, o facto de não existir uma canção vencedora, mas quatro, é prova de que este facto não passou de uma intenção. O propósito deste evento foi, acima de tudo, preparar o I Concurso de Intérpretes da Canção Ligeira que, segundo o mesmo regulamento, estava previsto para outubro do mesmo ano, 1960.

Segundo a análise das grelhas de programação da RTP, e como é noticiado a 7 de janeiro de 1961 na RTV, o concurso previsto para outubro, só foi transmitido às $21.30 \mathrm{~h}$ do dia 28 de dezembro de 1960 . Podendo ser assumido como uma segunda edição do festival organizado em julho anterior, estiveram presentes intérpretes como Gina Maria, Mara Abrantes, Luís Piçarra, António Calvário e Manuel Mendes. Como compositores, estiveram representados Nóbrega e Sousa, Jorge Costa Pinto, Carlos Canelhas e José António Araújo Pereira.

Independentemente de considerarmos um único festival com duas ediçóes ou dois festivais mais ou menos autónomos, podemos concluir que foi o primeiro momento com música original propositadamente escrita para ser interpretada em televisão. Desta forma 


\section{$120 \mid$ João Ricardo Pinto \& Nuno Estêvão Ferreira}

podemos afirmar que é em 1960 que a RTP se torna um meio de comunicação criador de fluxos culturais que viriam a "alimentar" o meio mediático. Tal facto é revelado nos diferentes trabalhos discográficos que incluem a canção “Amanhã se Deus Quiser”, do I Concurso de Cançóes Ligeiras: , interpretada por António Calvário no EP coletivo O Papá e a Mamã (A Voz do Dono - 7LEM 3063), em 1960; por Fernando Franco no EP Amanhã Se Deus Quiser (Alvorada - AEP 60 441), em 1961; e por Maria Alice Ferreira no EP Confesso (Alvorada - AEP 60 463), também em 1961.

\section{Io Grande Prémio TV da Cançáo Portuguesa}

Após esta primeira tentativa de organização de um festival com componente competitiva, a RTP organiza com o apoio do SNI o Io Grande Prémio TV da Canção Portuguesa (GPTVCP), que se realizou a 2 de fevereiro de 1964, hoje designado Festival da Canção, mas vulgarmente conhecido por Festival RTP da Canção.

Num programa emitido a partir dos estúdios da RTP, com realização de Rui Ferrão e apresentação de Henrique Mendes (TV Semanário da Radiotelevisão Portuguesa, 23 jan., 1964), ao longo de cerca de uma hora (com início às 22.30h), são apresentadas 12 canções a concurso, sendo que a vencedora iria representar Portugal em 1964, no GPEC, que se realizou em Copenhaga a 21 de março.

A análise do regulamento do Io GPTVCP, publicado na notícia "Com vista à Eurovisão a R.T.P. Lança o Grande Prémio TV da Canção Portuguesa - 1964" (TV Semanário da Radiotelevisáo Portuguesa, 21 nov., 1963) revela desde logo que a sua organização tinha como objetivo
estimular a produção de canções originais de nível internacional que pudessem com- petir com cançóes de outros países europeus no certame internacional denominado Grande Prémio Eurovisão 1964 da Canção Europeia (Regulamento do Io GPTVCP 1964: ponto II - Objectivo).

Embora os intérpretes possam ter sido escolhidos de comum acordo entre os compositores e a RTP, "os intérpretes que apresentavam as cançóes concorrentes eram, na sua maioria, formados no Centro de Preparação de Artistas da EN" (Lopes, 2012, p.162) e já com carreiras consolidadas. Este facto leva a crer que, ou se tratou de uma grande coincidência, ou a RTP teve um grande "peso" na escolha dos intérpretes, todos eles vedetas associadas ao campo dos media tendo cada um dos escolhidos interpretado duas cançóes. No entanto, também importa referir que, para os compositores, também eles já consagrados, era igualmente importante que os cantores fossem intérpretes famosos, uma garantia de visibilidade e qualidade.

A vencedora do GPTVCP foi a canção "Oração”, interpretada por António Calvário. Com letra de Rogério Bracinha e Francisco Nicholson, e música de João Nobre, a letra de teor religioso aproxima-se da temática do perdáo, um ato de contrição. Muito embora existam diferentes versões desta canção ao longo dos tempos, em 1964 é editada duas vezes: interpretada por Tony de Matos no EP coletivo Grande Prémio da Canção Portuguesa - TV-1 (Alvorada - AEP 60 644) e por António Calvário numa versão orquestral dirigida pelo maestro Joaquim L. Gomes (A Voz do Dono - 7LEM3131). 
Embora tenha obtido grande sucesso em Portugal, a sua apresentação no GPEC em 1964 ficou marcada pela ausência de qualquer ponto atribuído, o que poderá ter acontecido em parte pelo facto de em Portugal vigorar um regime político ditatorial. Contudo, este não poderá ser considerado como único fator para tal pontuação. Espanha, país no qual também vigorava um regime político com características idênticas, obteve um ponto atribuído pelo júri italiano.

As questóes políticas, nomeadamente no que diz respeito à Península Ibérica, estiveram muito presentes no GPEC de 1964. Embora não existam imagens devido a um incêndio que destruiu o arquivo da televisão dinamarquesa, país onde se realizou o festival em 1964, durante a atuação suíça, um espectador subiu ao palco com uma faixa onde se lia "Boicotem Franco e Salazar" (Eurovision, tradução nossa); uma clara referências às ditaduras vigentes em Espanha e Portugal, respetivamente.

\section{Letras das cançóes}

O tema da oração perpassa a letra de "Senhora da Nazaré" e possui destaque máximo em dois títulos: "Oração" e "Oração para Dois". Nestas duas letras, o tópico do perdão é igualmente manifesto, ocupando espaço central na primeira. Já “a cruz" constitui o tema específico em "Crucifixo". Nestas quatro letras, é muito vincado o corte entre a divindade e a humanidade, situada numa posição de clara subalternização. Em "Amanhã se Deus Quiser", a religiosidade é secundária, mas o providencialismo ocupa destaque, enquanto que, em "À Porta de Nosso Senhor", o ambiente tradicionalista e conservador, com as romarias e o adro da igreja nas aldeias, fornece o universo de título e letra.

O catolicismo é a matriz central, de forma mais evidente em "Senhora da Nazaré" e "Crucifixo". As seis letras evocam uma religiosidade tradicional. As aldeias e os universos da ruralidade ou das atividades piscatórias são espaços onde emergem os tópicos do amor e do perdão, importantes no catolicismo. Mesmo que menos frequentes, são enfatizadas instituiçóes tradicionais e cruciais no ideário salazarista, como o casamento ou as festas populares de matriz religiosa, caso da romaria, com locais de convívio onde sagrado e profano se conjugam, caso do adro da igreja, e das invocaçóes marianas, caso da "Senhora da Nazaré".

A relação entre a humanidade e o sagrado é de subalternização completa da primeira em face deste último. Mesmo um tratamento mais direto ("tu") é insuficiente para desfazer a conceção antropomórfica de base, assente nas enormes fragilidade e pequenez humanas perante a grandiosidade do "Senhor, meu Deus". A lógica providencialista é, portanto, a prevalecente.

"Senhora da Nazaré" foi a primeira canção de temática religiosa interpretada num festival de música ligeira em Portugal. Assenta na equiparação entre a vida humana e a figura do pescador, que se movimenta num "barquito de sonho" e anda "ao largo" nas "vagas sem fim". Verifica-se o contraste entre a fragilidade do barco e a vastidão do oceano. As atividades piscatórias oferecem recursos estilísticos que caracterizam os sentimentos: "desilusôes" colhidas após lançamento das redes "com confiança" e o medo de "quase a naufragar". Também a navegação fornece recursos semelhantes: a direção da proa, a perda do "leme da esp'rança" e a incapacidade de "remar assim". 
Estes recursos possuem os mesmos pontos de partida e de chegada: o refrão, com o pedido "Senhora da Nazaré, rogai por mim". O universo religioso caracteriza-se pelo contraste entre a fragilidade humana e a dimensão divina, que necessita de mediaçóes. Invocada numa zona piscatória do centro do país, a Senhora da Nazaré é a intercessora escolhida pelo letrista João Nobre para superar as desilusóes, a quebra de confiança e de esperança ou o medo do naufrágio. $\mathrm{O}$ universo religioso possui uma lógica providencialista, onde as figuras do sagrado garantem a existência perante adversidades.

Classificada como "redentora" e com "poder profundo" atribuído por "Jesus Cristo", a "cruz" situa-se no centro da letra de Eduardo S. Oliveira. No título, "Crucifixo", e ao longo do texto, a inscrição no cristianismo é inequívoca. Da "cruz" emana uma "divina chama" que lhe permite ser "meu sol" e "eterno farol". O tema da luz é invocado em registo de ação: "dando luz" e "iluminas". Classificada como "redentora” e com "poder profundo" atribuído por "Jesus Cristo", é a "Cruz" que se situa no centro de "Crucifixo". $\mathrm{Na}$ letra de Eduardo S. Oliveira, a inscrição no plano do cristianismo resulta claramente dos termos "crucifixo" e "cruz", no título e no texto. Da "cruz" emana uma "divina chama" que lhe permite ser "meu sol" e "eterno farol". O tema da luz é invocado em registo de ação: "dando luz" e "iluminas".

A fragilidade da humanidade e de "todo o mundo" assim como uma posição de subalternidade são novamente vincadas: "dos que soçobram”, "joelhos se dobram”, "cabeça se curva". O tópico da luz permite fazer o contraste e realçar diversos benefícios, como "minha vista se turva", "meu olhar se fita" ou "nos apontas o céu". Entre estes, destacam-se os que se encontram sublinhados no refrão: "amar", "vencer" e "viver".

Termos como "vista”, “joelhos" e "cabeça” remetem para a dimensão corpórea. A "nossa alma” é, no refrão, o registo central, a par de "amor e fé". Os verbos empregues demonstram níveis de ação; "seduz", "convence", "inspirando" ou "certeza obtive".

O tema da letra escrita por Silva Tavares e interpretada no IIo Festival da Canção Portuguesa, "À Porta de Nosso Senhor", remete para o universo das romarias e dos bailes no adro da igreja. No centro do texto situa-se o amor: "o coração do meu peito p'ra o teu vai saltar!"). A génese da relação de amor entre duas pessoas ocorreu naquele contexto ("à porta da casa de Nosso Senhor"). Caracterizados pela periodicidade, romarias e bailes permitem antecipar ocasióes de encontro entre os dois apaixonados: "se há romaria, contigo lá estou todo o Santo dia no vira virou". O sujeito da letra é uma mulher e a paixão com o "meu bem" carateriza-se pela jura de amor em ordem ao casamento: "ficarei para tia, crê, se não me casar contigo!".

$\mathrm{Na}$ letra de "Oração para dois" é igualmente percebida uma relação entre dois interlocutores: "eu" e "Senhor". Nas estrofes, nota-se uma terceira figura, claramente vinculada à primeira: "nosso amor" e "pelos dois". "Senhor" é tratado sempre na 2. a pessoa do plural, traduzindo uma maior distância. O "meu Deus" situa-se "lá no alto dos Céus", de onde emanam "ordens" traduzidas na "Vossa lei", destinada a "servir".

A par do amor, Vitorino de Sousa sublinha o tema do perdão: "perdoai-me" e "pedir-Vos perdão". As circunstâncias são negativas: "vida é triste a pecar", "contra as ordens dos Céus", "o mal”, "não sentir a paz" e "as horas más”. Subalternização e posição de dependência são claras, marcando a oração e a súplica por uma resposta: "só me resta rezar e pedir-Vos perdão", "que o nosso amor Seja igual ao amor de Deus". 
Em "Amanhã se Deus quiser", o amor constitui o tema central, a figura de Deus é somente lugar de esperança numa relação ("sou para ti" e "tu para mim") que se pretende estabelecer: "Amanhã há-de nascer o Amor!”. Na letra de Jerónimo de Bragança, a expressão "espero em Deus amanhã dizer", somente se regista no título e no início da primeira estrofe. Típica da linguagem comum, esta expressão traduz a expectativa e a confiança no sagrado.

O tema do perdão atravessa a letra que representou a música ligeira feita em Portugal pela primeira vez no GPEC. Em "Oração", o termo "Senhor" surge por 14 vezes, "amor" encontra-se em seis linhas diferentes e "perdáo" em cinco. O ponto de exclamação remata 16 das 38 linhas, 12 das quais somente com o termo "Senhor". O dramatismo é também acentuado por uma relação unívoca, entre o próprio ("eu”) e interlocutor ("o "Senhor"), a quem se dirige insistentemente e cuja resposta poderá ser o perdão. Percebe-se ainda uma terceira figura ("a perdi” e "a adoro") que justifica os reiterados pedidos de perdáo: "meu amor maltratei!" e "meu amor desprezei”.

O próprio é repetidamente desqualificado: "pequei!", "choro", "errei” ou "perdido na dor!”. A sua subalternização justifica-se pelo "perjúrio de tantas promessas!” em face do amor, "o mais puro amor!", "o amor que é castigo", "mais puro que a joia mais rara" e que "na vida jamais encontrara!”. É perante um passado que já não pode ser resolvido (“é tarde!”) que surge a assunção: “confesso”, "perdão aqui peço” e “imploro!”. O perdão é reclamado junto do interlocutor principal ("Senhor"), qualificado como "meu Deus", "a redenção!" e "bondade infinita", na mais completa subalternidade do próprio: "a teus pés", "não mereço!" e "não t'esqueças da minha oração!".

\section{Consideraçóes finais}

O trabalho desenvolvido por António Ferro enquanto responsável pela propaganda, que tinha por base a ideologia política do Estado Novo, a visão da sociedade e a relaçáo, embora ambivalente, com a Igreja Católica, alterou o percurso da música ligeira no contexto português. Seja do ponto de vista musical, pela renovação do repertório através da adaptação de melodias rurais ou do folclore nacional, seja pela integraçáo de temáticas religiosas, das quais o catolicismo foi a principal matriz.

A continuidade da Política do Espírito, por um lado, e a preocupação da imagem do regime no estrangeiro, por outro, durante o período em que César Monteiro Baptista liderou o SNI, permitiram que o esforço realizado por António Ferro, a partir da década de 1940, resultasse na primeira participação de Portugal no GPEC em 1964. A presença do religioso na canção "Oração", e que perpassa igualmente outras letras apresentadas em festivais anteriores, surge de uma forma expressa, só por si, mas também em associação com a visão tradicional intrinsecamente associada à religião católica, tão cara aos principais ideólogos e arquitetos do regime.

Apesar de algumas flutuaçóes, a continuidade estratégica e a estabilidade das estruturas do Estado Novo não se limitaram ao plano da propaganda ou ao campo da cultura. Os alicerces e os principais instrumentos do regime foram fixados em 1933 e, apesar das alteraçóes introduzidas, perduraram ao longo de décadas, inclusivamente no 
período de governação de Marcello Caetano, sucessor de Salazar. De facto, a partir de 1968, as "mudanças cosméticas foram muitas" (Martinho, 2016, p. 414), abrangendo as denominaçōes do partido único, da censura ou da polícia política, mas todas as instituições se mantiveram ativas, prosseguindo os objetivos de sempre. Já com Salazar, o SPN vira a sua denominação ser alterada para SNI, com a valorização de "informação" em substituição de "propaganda". Dessas modificaçóes, contudo, não resultaram ruturas nas conceçôes de fundo sobre a sociedade nem nas estratégias políticas dos ideólogos e responsáveis máximos do Estado Novo.

Num quadro geral de continuidade estratégica de um regime e dos seus instrumentos centrais, a promoção de música ligeira de temática religiosa não se afigura estranha. As conotações religiosas de algumas letras e até títulos usados nesta nova categoria musical constituem o corolário de uma doutrinaçáo que perdurou no tempo e na qual o poder político e a Igreja Católica mantinham interesses convergentes. A trilogia pedagógica "Deus, Pátria e Família" ganhava nova expressão. A sua vulgarização surtia efeitos em novas áreas. A tal ponto que, quando a componente espetáculo e a vertente competitiva assumiram projeção internacional, é uma letra pejada de tópicos de religiosidade que é constituída como veículo de representação.

Embora estes festivais estivessem associados aos novos meios de comunicaçáo, nomeadamente à televisão, um sinal de vanguarda, o cumprimento das regras definidas nos regulamentos, aos quais os autores estavam ancorados, as escolhas dos júris e o olhar atento da censura, não permitiam que, do ponto de vista musical e literário, se verificassem alteraçóes profundas. Pelo contrário, validavam a "exploração de fontes tradicionais, das suas raízes rurais e da sua história singular” (Abreu, 2010, p. 252), tendo como resultado cançóes que provinham de uma matriz cultural produzida pela propaganda do regime na esfera da cultura popular, ou seja, mais próxima das camadas sociais menos instruídas.

\section{Referências}

ABREU, Paula. A Música entre a Arte, a Indústria e o Mercado - Um Estudo sobre a Indústria Discográfica em Portugal. 453f. Tese (Doutorada em Sociologia), Faculdade de Economia - Universidade de Coimbra, Coimbra, 2010.

ALIZART, Mark. Pop Théologie. Paris: Presses universitaires de France, 2015.

ALVES, José Felicidade (Org.). Católicos e política de Humberto Delgado a Marcello Caetano. Lisboa: Tip. Leandro, 1970.

ALVES, Vera Marques. O SNI e os Ranchos Folclóricos. In CASTELO-BRANCO, Salwa; BRANCO, João Freitas (Org.), Vozes do Povo. Oeiras: Celta Editora, 2003.

CARVALHO, Rita Almeida de. Concordata de Salazar. Lisboa: Temas e Debates, 2013.

CARVALHO, Rita Almeida de (Org.). António Oliveira Salazar - Manuel Gonçalves Cerejeira. Correspondência Política (1928-1968). Lisboa: Temas e Debates, 2010. 
CARVALHO, Rita Almeida de; ARAÚJO, António de, A voz dos sinos: o 'diário' de Mário de Figueiredo sobre a crise política de 1929, Estudos, n.o 4, Coimbra, p.459489, 2006.

CARVALHO, Rita Almeida de; RAIMUNDO, Filipa; FERREIRA, Nuno Estêvão. Decisão política no Estado Novo, 1933-1939: o ditador, o conselho de ministros e o seu 'núcleo duro'. In PINTO, António Costa (Org.). Governar em Ditadura: Elites e Decisão Política nas Ditaduras da Era do Fascismo. Lisboa: Imprensa de Ciências Sociais, 2012, pp.145-174.

CASTELO-BRANCO, Salwa; CIDRA, Rui. Música Popular. In CASTELOBRANCO, Salwa (Org.), Enciclopédia da Música em Portugal no Século XX, Vol. L-P. Lisboa: Círculo de Leitores, 2010, pp.875-878.

CRUZ Manuel Braga da. A revoluçáo nacional de 1926: da ditadura militar à formação do Estado Novo. Revista de História das Ideias, 7, Coimbra, p.347-371, 1985.

DOMINGOS, Nuno; PEREIRA, Victor (Org.). O Estado Novo em Questão. Lisboa: Ediçóes 70, 2010.

EUROVISION. Protest on stage. s.d. Disponível em: https://eurovision.tv/event/ copenhagen-1964. Acesso em: 28 maio, 2020.

FERREIRA, António Matos. Le christianismo dans l'Europe de la première moitiè du XXe siècle. La Péninsule Ibérique. In MAYEUR, Jean-Marie (Org.). Histoire du Christianisme des origines à nos jours. Paris: Desclée/Fayard, 1990, pp.402-450.

FERRO, António. A fé o império. Lisboa: Edições SPN, 1935.

GUEDES, Fernando. António Ferro e a sua Política do Espírito. Lisboa: Academia Portuguesa da História, 1997.

LOPES, Sofia Vieira. <<Duas horas vivas numa TV morta > : Zip-Zip, Música e Televisão no preâmbulo da democracia em Portugal. 182f. Tese (Mestre em Etnomusicologia). Faculdade de Ciências Sociais e Humanas - UNL, Lisboa, 2012.

LUCENA, Manuel de Salazar, António de Oliveira. In BARRETO, António; Mónica, Maria Filomena (Org.). Dicionário de História de Portugal, v. IX. Lisboa: Figueirinhas, 2000, pp.283-368.

MARTINHO, Francisco Carlos Palomanes. Marcello Caetano. Uma biografia, 1906-1980. Lisboa: Objectiva, 2016.

MATOS, Helena. Salazar. A construção do mito, v. 1. Lisboa: Temas e Debates, 2003.

MATOS, Helena. Salazar. A propaganda, v. 2. Lisboa: Temas e Debates, 2004.

MATOS, Luís Salgado de. Cardeal Cerejeira. Um patriarca de Lisboa no século XX português. Lisboa: Gradiva, 2018. 
MATOS, Luís Salgado de. A separaçáo do Estado e da Igreja. Concórdia e conflito entre a Primeira República e o catolicismo. Alfragide: Dom Quixote, 2011.

MELO, Daniel. Salazarismo e cultura popular (1933-1958). Lisboa: Imprensa de Ciências Sociais, 2001.

MENESES, Filipe Ribeiro de. Salazar. A political biography. New York: Enigma Books, 2010.

MOREIRA, Pedro; CIDRA, Rui; CASTELO-BRANCO, Salwa. Música Ligeira. In CASTELO-BRANCO, Salwa (Org.), Enciclopédia da Música em Portugal no Século XX, Vol. L-P. Lisboa: Círculo de Leitores, 2010, pp.872-875.

MOREIRA, Pedro. "Cantando espalharei por toda a parte”: programação, produção musical e o "aportuguesamento" da "música ligeira" na Emissora Nacional de Radiodifusão (1934-1949). 339f. Tese (Doutorado em Etnomusicologia), Faculdade de Ciências Sociais e Humanas - Universidade Nova de Lisboa, Lisboa, 2012.

MOURA, Maria Lúcia Brito de. A guerra religiosa na Primeira República. 2. a ed. Lisboa: Centro de Estudos de História Religiosa, 2010.

Ó, Jorge Ramos do. Os anos de Ferro. O dispositivo cultural durante a política do espírito, 1933-1949. Ideologia, instituiçóes, agentes de práticas. Lisboa: Estampa, 1999.

PAULO, Heloísa. Estado Novo e propaganda em Portugal e no Brasil. O SPN/SNI e o DIP. Coimbra: Minerva, 1994.

PINTO, João Ricardo. "Onde? Como? Quanto? Quando?” - a produção musical nos primórdios da Radiotelevisão Portuguesa (1956-1964). 390f. Tese (Doutorado em Etnomusicologia), Faculdade de Ciểncias Sociais e Humanas - Universidade Nova de Lisboa, Lisboa, 2019.

PINTO, Sérgio Ribeiro. Separação religiosa como modernidade. Decreto-lei de 20 de abril de 1911 e modelos alternativos. Lisboa: Centro de Estudos de História Religiosa, 2011.

ROSAS, Fernando. O Estado Novo (1926-1974). Lisboa: Estampa, 1994.

SALAZAR, António de Oliveira de. Discursos e notas políticas, v. 5. Coimbra: Coimbra Editora, 1959.

SANTOS, Graça dos. "Política do espírito": O bom gosto obrigatório para embelezar a realidade. Media \& Jornalismo, v. 12, p.59-72, 2008.

SILVA, Manuel Deniz. Rádio. In CASTELO-BRANCO, Salwa (Org.), Enciclopédia da Música em Portugal no Século XX, v. P-Z,. Lisboa: Círculo de Leitores, 2010. pp.1080-1087.

SIMPSON, Duncan. A Igreja Católica e o Estado Novo salazarista. Lisboa: Ediçóes 70, 2014. 
TUNA, Cátia. Não sei se canto se rezo: ambivalências culturais e religiosas do fado (1926-1945). $726 f$ (v. I), $393 \mathrm{f}$ (v. II). Tese (Doutorada em História e Cultura das Religióes). Faculdade de Letras - Universidade de Lisboa, Lisboa, 2020.

Recebido: $16 / 07 / 2020$

Aprovado: 19/11/2020

Editor: Alfredo Teixeira 